\title{
Organization as a Support System among Revert Clients in Malaysia
}

\section{Samsiah Jayos ${ }^{1 *}$, Faizah Abd Ghani ${ }^{2}$, Lokman Mohd Tahir ${ }^{3}$, Kamarul Azmi Jasmi ${ }^{4}$ and} Nur Fatihah Abdullah Bandar ${ }^{5}$

${ }^{1,5}$ Universiti Malaysia Sarawak, 94300 Kota Samarahan, Sarawak, Malaysia

${ }^{2,3}$ Faculty of Educations, Universiti Teknologi Malaysia, Johor, Malaysia

${ }^{4}$ Faculty of Islamic and Civilization, Universiti Teknologi Malaysia, Johor, Malaysia

\begin{abstract}
It is significant for the reverts to have an existing helping organization. Therefore, this study aims to identify organizational issues that are directly and indirectly involved with counsellors at the Council of Islamic Religious Department in Malaysia. This study utilizes a qualitative approach by using the case study method. This study involved five (5) counsellors from Council of Islamic Religious Department in Malaysia. This study used the N'Vivo 10.0 for the data analysis to develop themes and sub-themes that related to this study. The findings showed that there are two (2) sub themes involved both government and non-government. There are six (6) sub-sub themes for the government which are Jabatan Agama Islam, Jabatan Mufti, Pusat Dakwah Islamiah, Pusat Kaunseling MAINS Negeri Sembilan, Jabatan Kehakiman and Baitulmal. While, non-government has ten (10) sub-sub themes; Lembaga Kaunselor Malaysia, Unit Saudara Baru, Unit Ukhuwah, Pusat Saudara Baru Darul Saadah, Darul Ukhuwah Yayasan Kasih Sayang, Volunteer Body, Malaysian Chinese Muslim Association (MACMA), Pertubuhan Kebajikan Islam Malaysia (PERKIM), PERKAMA and Skuad Mubaligh Seremban. In conclusion, this study could be used as a guide for counsellors to provide guidance and counselling services to revert clients.
\end{abstract}

Keywords: Organization; support system; revert and client.

\section{INTRODUCTION}

\section{ARTICLE INFO}

E-mail address:

jsamsiah@unimas.my (Samsiah Jayos)

*Corresponding author

e-ISSN: 2550-1623

(C) Faculty of Cognitive Sciences and Human Development, Universiti Malaysia Sarawak (UNIMAS)
Counselling functions as a service to help and support in the process of human development in Malaysia (Suradi \& Rafidah Aga, 2005). This service has been around for almost 57 years starting since 1960 and has grown from being in school to the organization level 
(Mohamed Sharif et al., 2005). Counselling is currently gaining popularity in government organizations or private sectors. Reverts are social beings who are concerned by various problems connected with family, colleagues, neighbours and other people in life (Anis Hidayah Ismail, Samsiah dan Rizal, 2009). Hence, they need support to deal with their emotional, physical, intellectual and spiritual life (Samsiah, Faizah, Lokman, Kamarul \& Nur Fatihah, 2014). Islamic counselling approach does provide help for the reverts (Loh, 2005). Therefore, clients can be helped with the best, registered counsellors that are fully considered as the professionals (Michalos, 2001; Othman, 2008).

\section{THEORIES}

There are two theories involved in this study. First, Theory of Task and Group Support Systems Effectiveness by Alken, Buckland, Zigurs \& Kathleen (2007), emphasize on the importance of organizing the needs of a person in his/her life. Second, the Maslow's Hierarchy (Henwood, Derejko, Couture \& Padgett, 2015) is also relevant to the needs of a person before one reaches the level of a perfect life. The first stage is physiological-physique involving basic needs such as eating and drinking needs. The second stage is the level of safety that is the requirement that a person needs to feel safe and secure from dangerous threats that includes a safe place and support each other (Mohd Rosmizi, 2010). Hence, this study sought to identify the support system to assist revert clients in Malaysia.

\section{METHODOLOGY}

The study is done in counselling departments and religious councils in Malaysia. The primary focus in qualitative research is to obtain rich and in-depth data (Cohen, Manion \& Morrison, 2007). Data for this research was collected using a case study and involved five (5) registered counselors in Islamic Organization in Malaysia. This study was based on a qualitative approach and data was analyzed using N'Vivo 10.0 (Cashwell, Young, Cashwell \& Belaire, 2001; Dayang Tiawa \& Abdul Hafidz, 2009). Participants were reverts and they were interviewed by Muslim counsellors during their counselling sessions.

\section{RESULTS AND DISCUSSIONS}

Table 1 presents the respondent's demographics and Table 2 presenting the organization support system among revert clients both government and nongovernment. Table 2 showed that there are two (2) sub themes involved both government and non-government. There are six (6) sub-sub themes for the government which are Jabatan Agama Islam, Jabatan Mufti, Pusat Dakwah Islamiah, Pusat Kaunseling MAINS Negeri Sembilan, Jabatan Kehakiman and Baitulmal. While, non-government has ten (10) sub-sub themes; Lembaga Kaunselor Malaysia, Unit Saudara Baru, Unit Ukhuwah, Pusat Saudara Baru Darul Saadah, Darul Ukhuwah Yayasan Kasih Sayang, Volunteer Body, 
Table 1: Responder Demographics

\begin{tabular}{cccccc}
\hline No.(CR) & Gender & $\begin{array}{c}\text { Age } \\
\text { (year) }\end{array}$ & $\begin{array}{c}\text { Marital } \\
\text { Status }\end{array}$ & $\begin{array}{c}\text { Duration } \\
\text { Service }\end{array}$ & $\begin{array}{c}\text { Counsellor } \\
\text { Status }\end{array}$ \\
\hline CR1 & Man & 40 & Married & 14 & Registered \\
\hline CR2 & Women & 38 & Married & 10 & Registered \\
\hline CR3 & Man & 41 & Married & 15 & Registered \\
\hline CR4 & Women & 35 & Married & 4 & Registered \\
\hline CR5 & Women & 28 & Married & 3 & Registered \\
\hline
\end{tabular}

Indicator: $\mathrm{CR}=$ Counsellor Respondent

Malaysian Chinese Muslim Association (MACMA), Pertubuhan Kebajikan Islam Malaysia (PERKIM), PERKAMA and Skuad Mubaligh Seremban. The da'wah management of the revert client can be understood as a matter of managing and maintaining things that are related to the efforts to give and to improve the understanding of the revert clients towards the teachings of Islam. At the beginning of the recitation, some of the revert client faced some problems that seemed to disturb the development of the Islamic preaching among them (Cashwell et al., 2001). The problems include: financial constraint, surviving, employment and learning. The relevant organization support system should be wise in assisting this particular group (Fa'izah, 2004; Alken, et al., 2007).

The major problems faced by the revert client are financial problems, housing and education (Ee Ah Meng, Suppiah Nachiappan \& Taquddin, 2011). This situation makes them less devoted and charitable in their Islamic practices. The responsible organization should responsible for giving guidance to revert clients (Ahmad \& Amer, 2012).
Table 2: Organization as a Support System among Clients Revert.

\begin{tabular}{|c|c|}
\hline \multicolumn{2}{|c|}{ Theme: Organizations } \\
\hline Sub-Theme & Sub-Subtheme \\
\hline \multirow[t]{6}{*}{ Government } & Jabatan Agama Islam \\
\hline & Jabatan Mufti \\
\hline & Pusat Dakwah Islamiah \\
\hline & Pusat Kaunseling, MAINS \\
\hline & Jabatan Kehakiman \\
\hline & Baitulmal \\
\hline \multirow{10}{*}{$\begin{array}{l}\text { Non- } \\
\text { Government }\end{array}$} & Lembaga Kaunselor Malaysia \\
\hline & Unit Saudara Baru \\
\hline & Unit Ukhuwah \\
\hline & Pusat SB Darul Saadah \\
\hline & $\begin{array}{l}\text { Darul Ukhuwah Yayasan } \\
\text { Kasih Sayang }\end{array}$ \\
\hline & Volunteer body (NGO) \\
\hline & $\begin{array}{l}\text { Malaysian Chinese Muslim } \\
\text { Association (Persatuan Cina } \\
\text { Muslim Malaysia, MACMA) }\end{array}$ \\
\hline & $\begin{array}{l}\text { Muslim Welfare } \\
\text { Organization Malaysia } \\
\text { (Pertubuhan Kebajikan } \\
\text { Islam Malaysia, PERKIM) }\end{array}$ \\
\hline & PERKAMA \\
\hline & 10. Skuad Mubaligh Seremban \\
\hline
\end{tabular}

In this study, counsellors need guidance in Islamic counselling to assist clients (Salasiah, 2008). This is the similar with the study by Peter Wong and Mohd Yussof (2010) who mentioned that Malaysian community faced numerous changes such as increased migration, increased life expectancy, divorce, changing family structures and illegal immigrants. This situation illustrates that 
the issue of cultural diversity has become an important part of counselling training. Multicultural counselling training should be emphasized in order to prepare counsellors to deal with the issue of cultural diversity among clients who are reverts (Fa'izah, 2004; Mohd Farhan, 2006). This is consistent with the focus of multicultural counselling training in America that gives primary attention to the practice of racial or ethnic majority and minority trainees (Ahmad \& Amer, 2012). According to Samsiah, Faizah and Lokman(2012),guidance and counselling services in Malaysia must be strengthened. Through this study, it is clear that reverts return to their previous religion easily especially to the young women who face divorce. Therefore, we recommend that registered counsellors need to more aware with the possible constraints that they will face including counsellor experience (language, time, clients' willingness), time commitment and unique client.

A person's well-being is closely related to his/her finance, knowledge, faith, relationship, and occupation. Hence, the organizations involved in matters relating to revert client should take the best possible steps to ensure the survival of this group. If this issue is not resolved, there will be phenomenon, such as apostasy, increased street beggars, the collapse of domestic institutions and the others (Mohammad Shukri Draman, 2010).

\section{CONCLUSION}

In conclusion, it is hoped that the study and the information obtained from this survey will be used by organizations in providing quality and support the counselor in providing counselling services to revert client clients in Malaysia. The results of this study are expected to assist respective organizations, especially those involved directly in the management of da'wah with revert clients. It is hoped that the findings of this study will strengthen the management of da'wah and counselling to help the revert client overcome their problem.

\section{ACKNOWLEDGEMENTS}

This research was sponsored by KPT/ UTM Johor (JB/PP093088).

\section{REFERENCES}

Ahmad, S. \& Amer, M.M. (2012). Counseling Muslim: Hand books of mental health issues and interventions. Routledge Taylor \& Francis Group New York, London.

Alken, S.J., Buckland, B.K., Zigurs, I. \& Kathleen, E. (2007). A Theory of Task and Group Support Systems Effectiveness. JSTOR: Social Service Review, 22(3).

Anis Hidayah Ismail, Samsiah Jayos dan Rizal Abu Bakar (2009). The Relationship of Emotional Intelligence and Agreeableness with Help Seeking Behaviour as the Moderating Factor. Prosiding Konvensyen Isu-isu Masyarakat 
Samsiah Jayos, Faizah Abd Ghani, Lokman Mohd Tahir, Kamarul Azmi Jasmi and Nur Fatihah Abdullah Bandar

2009. 4 - 5 April 2009. Fakulti

Sains Kognitif dan Pembangunan

Manusia (FSKPM), Universiti

Malaysia Sarawak (UNIMAS),

Sarawak, Malaysia.

Cashwell, C.S., Young, J.S., Cashwell,

T.H. \& Belaire, C. (2001). The

Inclusion of Spiritual Process in

Counseling and Perceived

Counselor Effectiveness.

Counseling and Values. Falls

Church:Jan 2001. 45(2), 145-146.

Cohen, L., Manion, L. \& Morrison, K.

(2007). Research Methods in

Education. London: Routledge.

Dayang Tiawa Awg Hamid \& Abdul

Hafidz Omar (2009). Analisis

Data Kualitatif. Nasmax Sdn. Bhd.

Skudai Johor dan Universiti

Teknologi Malaysai (UTM),

Skudai Johor.

Ee Ah Meng, Suppiah Nachiappan \&

Taquddin Abd Mukti (2011).

Perkhidmatan Bimbingan \&

Kaunseling. Oxford Fajar Sdn.

Bhd. (008974-T). Shah Alam

Selangor.

Loh Poh Fang (2005). Hubungan antara

ketakutan rawatan psikologi

dengan sikap mendapat bantuan

kaunseling. Unpublished thesis.

Universiti Putra Malaysia,

Serdang, Selangor.

Michalos, A.C. (2001). Ethics

Counselors as a New Priedthood.

Journal of Besiness Ethics, 29, 3-

17.

Mohamed Sharif Mustaffa, Roslee

Ahmad, Sulaiman Shakib Mohd

Noor dan Azizi Yahaya (2005).

Kemahiran Lanjutan dalam

Kaunseling. Penerbit Universiti
Teknologi Malaysia, Skudai

Johor.

Mohd Farhan Abdullah (2006).

Kristianisasi dan Gejala Murtad

di Malaysia. Seri Kembangan. Al

Khidmah Resource.

Mohd Rosmizi Abd Rahman (2010).

Introduction to Islamic and

Buddhist Personal Ethics. USIM

Publisher. Universiti Sains Islam

Malaysia, Bandar Baru Nilai,

Negeri Sembilan.

Othman Mohamed (2008). Amalan

Penyeliaan Kaunseling. Penerbit

Universiti Putra Malaysia,

Serdang.

Fa'izah Paijalah, (2004). Persepsi

Saudara Baru Tentang

Penerimaan Masyarakat Islam

Terhadap Mereka: Kajian Kes di

Darul Ukhuwah Johor Bahru.

Unpublished report. Fakulti

Pendidikan. Universiti Teknologi

Malaysia, Skudai Johor.

Henwood, B.F., Derejko, K.S., Couture,

J. Padgett, D.K., (2015). Maslow and Mental Health Recovery: A Comparative Study of Homeless Progams for Adults with Serious Mental Illness. Adm Policy Mental Health, 42(2), 220-228.

Peter Wong Sin On \& Mohd Yussof Mohamad (2010). Spirituality and its Integration into Counsellor Education. Abidin. Pendekatan Dakwah dalam Aplikasi Teknik Kaunseling di Sekolah: Satu Kajian Literatur. Prosiding Konvensyen Kaunseling Kebangsaan dan Ekspo Inovasi dan Penyelidikan dalam Kaunseling. 13-15 Jun 2010, 
Fakulti Pengurusan dan Ekonomi Universiti Malaysia Terengganu (UMT), Terengganu.

Salasiah Hanin Hamjah (2008). Pendekatan Da'wah Al-Irsyad AlNafsiyy menurut Al-Ghazali: Satu Kajian di Pusat Kaunseling Majlis Agama Islam Negeri Sembilan.Unpublished thesis. Universiti Kebangsaan Malaysia. Bangi.

Samsiah Jayos, Faizah Abd. Ghani \& Lokman Mohd Tahir (2012).

Tinjauan Keperluan Penyediaan Model Kaunselor Saudara Baru di Malaysia. Prosiding di Makassar International Research Seminar (MIRS 2012). 17- 18 Feb. 2012. Lamacca Universitas Negeri Makassar (UNM), Hotel, Makassar, South Sulawesi, Indonesia.
Samsiah Jayos, Faizah Abd Ghani, Lokman Mohd Tahir, Kamarul Azmi Jasmi \& Nur Fatihah Abdullah Bandar (2014). System Support in Counselling among Revert Clients in Malaysia. Journal of Cognitive Sciences and Human Development, 1(1), 74-81.

Suradi Salim and Rafidah Aga Mohd Jaladin (2005). Development of Counselling Services in Malaysia. In Zafar Ansari, Noraini Noor \& Amber Haque (eds). Contemporary Issues in Malaysia Psychology. Malaysia: Thompson. Mohammad Shukri Draman (2010). Pengurusan Dakwah Terhadap Saudara Baru: Kajian Di Pejabat Agama Islam Daerah Klang Selangor Darul Ehsan. Tesis Ijazah Sarjana Usuluddin (Secara Disertasi) tidak diterbitkan. Kuala Lumpur: Universiti Malaya. 